\title{
Clinical approaches and satisfaction with analgesia of trauma victims with severe pain*
}

\author{
Condutas clínicas e satisfação diante da analgesia em vítimas de trauma com dor intensa
}

Andrea Regina Martin¹, Jamyle Rubio Soares ${ }^{1}$, Débora Comin Baronceli², Sonia Silva Marcon³, Mayckel da Silva Barreto ${ }^{1,2,3}$

${ }^{*}$ Received from School of Philosophy, Sciences and Letters of Mandaguari, Mandaguari, PR, Brazil.

DOI 10.5935/1806-0013.20150037

\section{ABSTRACT}

BACKGROUND AND OBJECTIVES: The profile of victims assisted by emergency units with severe pain and the satisfaction with analgesia should guide therapeutic approaches and care in such services. This study aimed at observing socio-demographic characteristics associated to severe pain in trauma victims and at evaluating whether there have been differences in clinical approaches and satisfaction with analgesia for those with moderate or severe pain.

METHODS: This is a descriptive cross-sectional study carried out with 83 patients with acute, moderate or severe pain after physical trauma. Data were collected in October 2013 by means of a structured tool with questions about socio-demographic profile and pain evaluation after initial medical assistance.

RESULTS: It was observed that $53.02 \%$ of respondents have classified pain at admission as severe, which was associated to age between 18 and 49 years and education less than eight years. Individuals with severe pain had higher chances of simultaneously receiving non-pharmacological measures and intravenous drugs, have reported improvement only 30 minutes after their administration and were not happy with analgesia.

CONCLUSION: Most patients were young, with education less than eight years and have reported severe pain. Dissatisfaction with analgesia was more frequent among severe pain patients. Health professionals should be alert for age and education characteristics when evaluating pain in trauma victims and should carefully evaluate clinical approaches to be used.

Keywords: Acute pain, Emergency medical services, Injuries, Pain handling, Pain measurement, Wounds.

1. Faculdade de Filosofia, Ciências e Letras de Mandaguari, Mandaguari, PR, Brasil.

2. Faculdade Intermunicipal do Noroeste do Parana, Loanda, PR, Brasil.

3. Universidade Estadual de Maringá, Maringá, PR, Brasil.

Submitted in March 15, 2015.

Accepted for publication in July 27, 2015.

Conflict of interests: none - Sponsoring sources: none.

Correspondence to:

Andrea Regina Martin

Rua Renê Táccola, 152 - Centro

86975-000 Mandaguari, PR, Brasil.

E-mail: andrea-deh@hotmail.com

(C) Sociedade Brasileira para o Estudo da Dor

\section{RESUMO}

JUSTIFICATIVA E OBJETIVOS: O perfil das vítimas de trauma atendidas nas unidades emergenciais com dor aguda intensa e a satisfação com a analgesia empregada devem direcionar a conduta terapêutica e as atividades assistenciais nesses serviços. Os objetivos deste estudo foram verificar as características sócio-demográficas associadas à ocorrência de dor intensa em vítimas de trauma e avaliar se houve diferença nas condutas clínicas e na satisfação com a analgesia para aqueles com dor moderada ou intensa.

MÉTODOS: Estudo descritivo e transversal realizado com 83 pacientes que apresentaram dor aguda, moderada ou intensa após trauma físico. Os dados foram coletados em outubro de 2013, mediante instrumento estruturado contendo questóes sobre o perfil sócio-demográfico e avaliação do quadro álgico, após $\mathrm{o}$ atendimento médico inicial.

RESULTADOS: Observou-se que 53,02\% dos entrevistados classificaram a dor na admissão como intensa, a qual esteve associada à idade entre 18 e 49 anos e escolaridade menor que oito anos. Os indivíduos com dor intensa apresentaram maiores chances de receber, de forma concomitante, medidas não farmacológicas e fármacos por via venosa, relataram melhora somente após 30 minutos da sua administraçáo e não ficaram satisfeitos com a analgesia.

CONCLUSÁO: A maioria dos pacientes era jovem, com escolaridade menor que oito anos e relatou dor intensa. A insatisfação com a analgesia foi mais observada nos pacientes com dor intensa. Profissionais de saúde precisam estar atentos às características de idade e escolaridade ao avaliarem a dor em vítimas de trauma e devem analisar as condutas clínicas utilizadas cuidadosamente. Descritores: Dor aguda, Ferimentos, Lesóes, Manuseio da dor, Mensuração da dor, Serviços médicos de emergência.

\section{INTRODUCTION}

Trauma is a major and current challenge for security and public health sectors in Brazil and in different parts of the world because accidents and deaths due to external reasons are increasing in recent years ${ }^{1-3}$. Acute pain is one of the most common consequences of trauma and its repercussions are considered potentially noxious for the body, being that the more severe and extensive is the injury, the higher is pain intensity ${ }^{4}$. 
Since the early 1990s, there is a broad and complex definition of pain, which is characterized as an unpleasant sensory and emotional experience associated to real or potential tissue injury, or described in terms of such injury ${ }^{5}$. It is also consensus that acute pain may trigger several neurovegetative changes, such as increased blood pressure, increased heart rate and output, hypoventilation and decreased peripheral blood perfusion which, in case of trauma patients, tend to worsen their clinical presentation ${ }^{4}$.

However, even with definitions and consensus established for decades, acute pain measurement in trauma victims has had little emphasis and applicability both in assistance practice and scientific literature. This is primarily due to the fact that health professionals are still not convinced of the biological, humanitarian and ethical importance of acute pain measurement to guide therapy and assistance, which certainly is reflected in less patients' satisfaction with analgesia ${ }^{6,7}$.

This study is justified by the fact that pain evaluation is important during painful trauma victims' assistance, and also because little is known about the profile of trauma victims assisted in first aid units with acute, moderate or mild pain, about most common clinical approaches and patients' satisfaction with analgesia ${ }^{8}$. This poor knowledge brings inconsistency to available information, impairing health professionals' sensitization to plan actions, programs and material and human resources allocation in first aid units to evaluate, treat and control acute pain?.

In light of the above, this study aimed at evaluating socio-demographic characteristics associated to acute pain in trauma victims, and at evaluating whether there was been differences in clinical approaches and satisfaction with analgesia among those with moderate or severe pain.

\section{METHODS}

This is a descriptive, cross-sectional study carried out in a public first aid unit in the South of Brazil. Interviews were carried out in a private place within the unit itself, after initial medical assistance and implementation of care and drug administration by the nursing team. A structured questionnaire was used with information about patients' socio-demographic profile, the traumatic event and instituted treatment. Data on prescribed analgesics and non-pharmacological procedures for pain relief (local compression, immobilization and cryotherapy) were collected from medical records.

To evaluate pain intensity and location, numeric pain scale (NPS), which varies from zero to 10 and allows the classification of pain as absent ( 0 ), mild ( 1 to 3 ), moderate ( 4 to 7 ) and severe (8 to 10), and body diagram (drawing of the human body where patients indicate the site of pain) were applied.

Data were collected in October 2013, from Monday to Friday, from 7:00 a.m. to 1:00 p.m., being considered potential participants all individuals aged above 18 years who came to the service with diagnosis of trauma and acute pain (103 patients). Exclusion criteria were patients who were intu- bated, sedated and unable to answer the questions due to trauma (8 cases) or those refusing to participate in the study ( 2 cases). In total, 93 patients were interviewed as from a non-probabilistic sample. Afterward, 10 more patients were excluded for presenting mild pain. It is believed that the distance between score 1 (onset of mild pain) and 7 (end of moderate pain) has prevented individuals to be included in the same group and that is why those with mild pain were excluded from the study.

\section{Statistical analysis}

Data were compiled by the program Microsoft Office Excel $2010^{\circ}$ and statistically analyzed with the software Statistical Analysis System - SAS. To observe the association of studied variables with the relevant outcome and to measure this association, Pearson non-parametric Chi-square test was used with significance level of $\mathrm{p}<0.05$ and Relative Risk (RR) was calculated.

This study was approved by the Permanent Ethics Committee for Research Involving Human Beings of the State University of Maringá (CAAE: 20517513.3.0000.0104-2013).

\section{RESULTS}

Sample was made up of 83 individuals being that at admission, $44(53.02 \%)$ had classified their pain as severe. With regard to socio-demographic characteristics, most were females, not white, without companion, aged between 18 and 49 years and education level equal to or less than eight years (Table 1).

There has only been association between more severe pain and age and education level. RR calculation has shown that individuals aged 18 to 49 years and with education level less than eight years had, respectively, 3.4 (CI: 1.75-6.57) times and 1.6 (CI:1.02-2.38) times more chance of classifying their pain as severe.

All participants of the study were pharmacologically medicated for pain relief, being subcutaneous (SC) or intramuscular (IM) the most common administration routes, with 63 cases $(75.90 \%)$. However, among individuals with severe pain, intravenous (IV) administration was significantly more frequent (Table 2).

Slighly more than half the respondents $(44-53.02 \%)$ have received non-pharmacological analgesia, being this significantly more prevalent among those with severe pain. Time for pain improvement after drug administration was more than 30 minutes for $55(66.27 \%)$ patients and this time was significantly longer for those with severe pain, although for most individuals of this group pharmacological analgesia has been administered by IV route, being simultaneously applied non-pharmacological pain control measures such as local compression, immobilization and cryotherapy.

Finally, it is of note that although $62(74.70 \%)$ of respondents were happy with analgesia 30 minutes after its administration, most unhappy patients had classified their initial pain as severe. 
Table 1. Socio-demographic characteristics of trauma victims according to pain level. Mandaguari, PR, 2013

\begin{tabular}{|c|c|c|c|c|c|c|c|}
\hline \multirow[t]{3}{*}{ Characteristics } & \multicolumn{4}{|c|}{ Pain intensity } & \multicolumn{2}{|c|}{ Total } & \multirow[t]{3}{*}{$p$ value } \\
\hline & \multicolumn{2}{|c|}{ Moderate } & \multicolumn{2}{|c|}{ Severe } & \multirow[b]{2}{*}{$\mathrm{n}$} & \multirow[b]{2}{*}{$\%$} & \\
\hline & $\mathrm{n}$ & $\%$ & $\mathrm{n}$ & $\%$ & & & \\
\hline Male & 18 & 21.68 & 21 & 25.30 & 39 & 46.98 & 0.88 \\
\hline Female & 21 & 25.30 & 23 & 27.72 & 44 & 53.02 & \\
\hline \multicolumn{8}{|l|}{ Race } \\
\hline Not white & 20 & 24.09 & 26 & 31.32 & 46 & 55.41 & \\
\hline \multicolumn{8}{|l|}{ Marital status } \\
\hline W/o companion & 21 & 25.31 & 24 & 28.92 & 45 & 54.23 & 0.94 \\
\hline With companion & 18 & 21.68 & 20 & 24.09 & 38 & 45.77 & \\
\hline \multicolumn{8}{|l|}{ Age (years) } \\
\hline$\leq 8$ & 17 & 20.49 & 29 & 34.93 & 46 & 55.42 & $0.04^{*}$ \\
\hline$>8$ & 22 & 26.50 & 15 & 18.08 & 37 & 44.58 & \\
\hline
\end{tabular}

*p significant according to Chi-square test.

Table 2. Distribution of pain relief characteristics and satisfaction with analgesia of trauma victims, according to pain level. Mandaguari, PR, 2013

\begin{tabular}{|c|c|c|c|c|c|c|c|c|}
\hline \multirow[t]{3}{*}{ Characteristics } & \multicolumn{4}{|c|}{ Pain intensity } & \multicolumn{2}{|c|}{ Total } & \multirow[t]{3}{*}{$p$ value } & \multirow[t]{3}{*}{$\mathrm{RR}(\mathrm{Cl})$} \\
\hline & \multicolumn{2}{|c|}{ Moderate } & \multicolumn{2}{|c|}{ Severe } & \multirow[b]{2}{*}{$\mathrm{n}$} & \multirow[b]{2}{*}{$\%$} & & \\
\hline & $\mathrm{n}$ & $\%$ & $\mathrm{n}$ & $\%$ & & & & \\
\hline \multicolumn{9}{|l|}{ Administration route } \\
\hline Intramuscular \& subcutaneous & 34 & 40.96 & 29 & 34.94 & 63 & 75.90 & \multirow[t]{2}{*}{$0.02^{*}$} & 2.7 \\
\hline Intravenous & 05 & 6.03 & 15 & 18.07 & 20 & 24.10 & & $(1.14-6.21)$ \\
\hline \multicolumn{9}{|l|}{ Non-pharmacological approaches } \\
\hline Yes & 14 & 16.87 & 30 & 36.15 & 44 & 53.02 & \multirow[t]{2}{*}{$0.00^{\star}$} & \multirow{2}{*}{$\begin{array}{c}1.9 \\
(1.24-2.91)\end{array}$} \\
\hline No & 25 & 30.12 & 14 & 16.86 & 39 & 46.98 & & \\
\hline \multicolumn{9}{|l|}{ Time to improve } \\
\hline$\leq 30$ minutes & 24 & 28.91 & 04 & 4.82 & 28 & 33.73 & \multirow[t]{2}{*}{$0.00^{*}$} & \multirow{2}{*}{$\begin{array}{c}2.4 \\
(1.69-3.30)\end{array}$} \\
\hline$>30$ minutes & 15 & 18.07 & 40 & 48.20 & 55 & 66.27 & & \\
\hline \multicolumn{9}{|l|}{ Satisfaction with analgesia } \\
\hline Yes & 33 & 39.75 & 29 & 34.95 & 62 & 74.70 & \multirow[t]{2}{*}{$0.00^{\star}$} & \multirow{2}{*}{$\begin{array}{c}4.3 \\
(2.32-7.91)\end{array}$} \\
\hline No & 06 & 7.23 & 15 & 18.07 & 21 & 25.30 & & \\
\hline
\end{tabular}

${ }^{*} \mathrm{p}$ significant according to Chi-square test; $\mathrm{RR}=$ relative risk; $(\mathrm{Cl})$ = confidence interval.

\section{DISCUSSION}

According to our results, it was observed that most respondents have classified their pain as severe. This has to be highlighted because emergency service professionals have to pay attention to pain measurement and consider different pain levels, especially those classified as severe by trauma patients. Within this perspective, a study carried out in a teaching first aid unit in Southeastern Brazil with 309 patients with clinical and traumatic problems has observed that mean pain at admission was 8.12 according to NPS, which characterized it as severe ${ }^{10}$.

It is known that acute and severe pain is a major reason for looking for first aid services ${ }^{11}$. However, even being a frequent symptom in this sector, there is a relative unpreparedness of health professionals to adequately deal with it, because they hardly consider socio-demographic characteristics when evaluating pain level, which may predispose to inadequate treatment ${ }^{6}$.

It has been observed that most individuals with severe pain were females. In fact, females seem to have a different pain threshold as compared to males. A study carried out in England and Libya, comparing males and females submitted to pain stimulation tests, has shown that males had higher tolerance and have used lower NPS scores to manifest their pain intensity ${ }^{12}$. 
Results of our study have shown that most trauma victims with severe pain had 18 to 49 years of age, were not white, without companion and with less than 8 years of education, profile also found in a different investigation ${ }^{10}$. Within these groups, it was observed that most common trauma triggers were traffic accidents, labor accidents and aggressions, which tend to be more severe leading to more intense painful processes ${ }^{1,2}$.

It has been observed that all individuals were medicated with analgesic drugs. Most common administration route was IM/ SC, being IV more common among those with severe pain. The explanation is based on the almost immediate pain relief when drugs are administered by this route. Drugs not suffering first pass metabolism through the liver occupy most part of its receptors, peaking with a faster and more effective analgesia $^{13}$.

More than half the respondents have also received non-pharmacological measures for pain relief, which were more significantly applied to those with severe pain. A study in a Dutch emergency unit with 1407 people with pain complaints has observed that only approximately $25 \%$ had received non-pharmacological measures ${ }^{14}$. These measures may increase the chances of adequate pain control in trauma victims and are a possibility to be prescribed and implemented.

One should stress that in spite of lack of time and deficit of professionals in first aid units, these measures, in addition to favoring pain control without potential risks for patients for being noninvasive measures, also decrease health service costs. Most respondents classifying pain as severe had higher chances of improving only 30 minutes after drug administration. This deserves attention, since a North-American study, carried out with more than 1 thousand patients of a first aid unit, has shown that pain diagnosis by professionals would take approximately 55 minutes to be established. In addition, almost 60 minutes were elapsed before medical analgesic prescription and administration by the nursing team ${ }^{15}$. This observation points to the compelling need for protocols allowing the decision-making by urgent measures aiming at solving this critical bottleneck of assistance, related to the long time for pain diagnosis, treatment and control in emergency units.

It is worth stressing that even taking longer than 30 minutes for pain improvement, most respondents (74.70\%) have reported being happy with analgesia. However, there has been less satisfaction among those with severe pain. A study carried out in a hospital from the Southeastern Brazil, with 309 patients, has shown that at hospital discharge approximately $70 \%$ of them still had pain, but even so, $60 \%$ have reported being happy with analgesia ${ }^{10}$.

Studies show a paradox between pain sensation and satisfaction with analgesia, although 50 to $76 \%$ of patients report being happy with the treatment they received for pain relief. It has to be considered that these studies, similar to our investigation, were carried out inside health units, where some patients were under observation. And the fact that respondents believed that they will would need again the health service in the future may have influenced their satisfaction with analgesia, being this a limitation of our study.

Moreover, the fact that this study was carried out in just one emergency health unit, with a limited number of patients, circumscribe our findings and does not allow generalizations.

\section{CONCLUSION}

Most patients were young, with less than eight years of education and have reported severe pain. Dissatisfaction with analgesia was more frequent among severe pain patients. We suggest that further investigations including a higher number of participants and with different trauma triggers are carried out. This would provide a more useful knowledge of trauma victims' profile, of most common clinical approaches and of users' satisfaction with analgesia, which shall certainly guide the way in which health professionals assist trauma victims in emergency units, especially those classifying their pain as severe.

\section{REFERENCES}

1. Andrade-Barbosa TL, Xavier-Gomes LM, Barbosa VA, Caldeira AP. Mortalidade masculina por causas externas em Minas Gerais, Brasil. Ciên Saúde Coletiva. 2013;18(3):711-9.

2. Hsia RY, Srebotnjak T, Maselli J, Crandall M, McCulloch C, Kellermann AL. The association of trauma center closures with increased inpatient mortality for injured patients. J Trauma Acute Care Surg. 2014;76(4):1048-54.

3. Odhiambo FO, Beynon CM, Ogwang S, Hamel MJ, Howland O, van Eijk AM, et al. Trauma-related mortality among adults in Rural Western Kenya: characterizing deaths using data from a health and demographic surveillance system. PLoS One. 2013;8(11):e79840

4. Sallum AM, Garcia DM, Sanches M. Dor aguda e crônica: revisão narrativa da literatura. Acta Paul Enferm. 2012;25(spe1):150.

5. International Association for Study of Pain (IASP). Consensus development conference statement: the integrated approach to the management of pain. Accid Emerg Med. 1994;6(3):291-2. http://consensus.nih.gov/1986/1986PainManagement055ht ml.htm.

6. Berben SA, Schoonhoven L, Meijs TH, van Vugt AB, van Grunsven PM. Prevalence and relief of pain in trauma patients in emergency medical services. Clin J Pain. 2011;27(7):587-92.

7. Magalhães PA, Mota FA, Saleh CM, Dal Secco LM, Fusco SR, Gouvêa AL. Percepção dos profissionais de enfermagem frente à identificação, quantificação e tratamento da dor em pacientes de uma unidade de terapia intensiva de trauma. Rev Dor. 2011;12(3):221-5.

8. Ribeiro NC, Barreto SC, Hora EC, de Sousa RM. [The nurse providing care to trauma victims in pain: the fifth vital sign]. Rev Esc Enferm USP. 2011;45(1):146-52. Portuguese.

9. Nascimento LA, Kreling MC. Assessment of pain as the fifth vital sign: opinion of nurses. Acta Paul Enferm. 2011;24(1):50-4.

10. Barreto RF, Gomes CZ, Silva RM, Signorelli AA, Oliveira LF, Cavellani CL, et al Avaliaçấo de dor e do perfil epidemiológico, de pacientes atendidos no pronto-socorro de um hospital universitário. Rev Dor. 2012;13(3):213-9.

11. Garcia VM, Reis RK. Adequação da demanda e perfil de morbidade atendida em uma unidade não hospitalar de urgência e emergência. Cienc Cuid Saude. 2014;13(4):66573.

12. Alabas OA, Tashani OA, Johnson MI. Effects of ethnicity and gender role expectation of pain on experimental pain: a cross-cultural study. Eur J Pain. 2012;17(5):776-86.

13. Ehret GB, Daali Y, Chabert J, Rebsamen M, Wolff A, Forster A, et al. Influence of CYP2D6 activity on pre-emptive analgesia by the n-methyl-d-aspartate antagonist dextromethorphan in a randomized controlled trial of acute pain. Pain Physician. 2013;16(1):45-56.

14. Berben SA, Schoonhoven L, Meijs TH, van Vugt AB, van Grunsven PM. Prevalence and relief of pain in trauma patients in emergency medical services. Clin J Pain. 2011;27(7):587-92.

15. Hwang H, Richardson L, Livote E, Harris B, Spencer N, Sean Morrison R. Emergency department crowding and decreased quality of pain care. Acad Emerg Med. 2008;15(12):1248-55. 